\title{
Adopting De Novo Programming Approach on IC Design Service Firms Resources Integration
}

\author{
James K. C. Chen \\ Department of Business Administration, Asia University, No. 500, Lioufeng Road, Wufeng, \\ Taichung 41354, Taiwan \\ Correspondence should be addressed to James K. C. Chen; kcchen@asia.edu.tw
}

Received 28 September 2013; Revised 23 December 2013; Accepted 23 December 2013; Published 18 February 2014

Academic Editor: Ching-Ter Chang

Copyright (C) 2014 James K. C. Chen. This is an open access article distributed under the Creative Commons Attribution License, which permits unrestricted use, distribution, and reproduction in any medium, provided the original work is properly cited.

The semiconductor industry has very important position in computer industry, ICT field, and new electronic technology developing. The IC design service is one of key factor of semiconductor industry development. There are more than 365 IC design service firms have been established around Hsinchu Science Park in Taiwan. Building an efficient planning model for IC design service firm resources integrating is very interest issue. This study aims to construct a planning model for IC design service firm implementation resources integration. This study uses the De Novo programming as an approach of criteria alternative to achieve optimal resource allocation on IC design firm. Results show the IC design service firm should conduct open innovation concept and utilizes design outsourcing obtains cost down and enhance IC design service business performance. This plan model of De Novo programming is not only for IC design service firm and also can apply to the other industrial implementation strategic alliance/integrating resource. This plan model is a universal model for the others industries field.

\section{Introduction}

The semiconductor industry has very important position in computer industry, information communication technology (ICT) field, and new electronic technology developing. The integrate circuit (IC) design is one of the key factors that influences semiconductor industry development to succeed or fail. Taiwan's semiconductor industry is successful case and complete supply chain system of IC industry. The IC design service is one of IC semiconductor industries that is a new business model of semiconductor manufacture process. The semiconductor's maker design IC by internal resource of firm in the past. Comparative, IC design with internal resource of firm is low efficiency and high cost than through design outsourcing. Outsourcing therefore is a crucial strategic decision for many organizational functions, namely, management of human resource, accounting, management of information systems, and management of supply chain [1]. A high performance supply chain system offers the right product, high quantity, delivery in right place, at right time, and reasonable price. Optimal production and design planning policies develop a centralized supply chain system under full information sharing at an e-business model [2]. Previous scholars have proposed many kinds of analytical approach as aids in conflict management of resource redistribution [3]. Among the numerous approaches available for conflict management, multicriteria decision making $(\mathrm{MCDM})$ is one of the most useful methodologies. MCDM is a dynamic situation process methodology that includs managerial level, operation level, engineering level, and business level [4].

Taiwan's semiconductor industry is a globalization industry that offers the DRAM, TQFP IC, SOP, TSOP and IC chip on global IC market. The IC semiconductor industry supply chain is a complete and strong infrastructure in Taiwan. The semiconductors industry includes IC design, IDM Faber, foundry, assembly, and test of IC. Specially, the IC design firm is a flexible business model which scale permit from one to hundreds of employees company. Therefore, how to integrate these IC design service firm's resources became a very important issue for IC semiconductors industries. This 
study aims to IC design service firm's resources integration, strategic alliance and resources allocation. We are utilizing the IC design service firm for empirical case study to examine the result of integrated resources. This paper introduces the De Novo programming in aid of criteria alternative for strategic alliance/resource allocation on IC design service firm $[5,6]$.

The issue of research innovation has attracted scholar attention and interest in the last century. Innovation varies in terms of products, services, processes, and business practices [7]. Open innovation means that valuable ideas/resources can come internally or externally from company. Chesbrough [8] points out "open innovation" is a paradigm that assumes firms can and should use external ideas as well as internal idea and through internal or external paths output the outcome of innovation technology to market. The firms can through authorization offer intellectual property (IP) to partner for new technology and also can spin-off new organization to market running new business. This study will be based on open innovation concept exploring the IC design service firm and how to integrate IC design industry resources and make optimal resources allocation in IC design service firm. This model of De Novo programming is not only for IC design service industry but also can apply to the other industrial implementation strategic alliance/integrating resource allocation.

The remainder of this paper is organized as follows. Section 2 discusses related theories of integrating resource planning model. Section 3 details the construction of an efficient planning model for integrating resource. Section 4 utilizes De Novo programming approach illustrating an empirical case to demonstrate how the proposed integrating resource model for IC design service firm. Section 5 presents conclusions, implications, and recommendations.

\section{Theoretical Background}

This section explores the related theoretical background of integrating resource planning model in the literature.

\subsection{Integrating Resource with Project Management. Previous} studies have often explored integrating resource using the resource-based view (RBV) of firm organization $[9,10]$. Holcomb and Hitt [11] describe tangible or intangible assets owned or controlled by firms as resources and organizational routines that allow firms to effectively integrate and use resources allocation to implement on their strategies planning. Resources have two key features: (1) they must enable the creation of organization's value and (2) this resources provide unique support that can resist duplicative efforts from the competitors [9]. A firm's competitiveness or operational performance always is dependent on their core resources it possesses [12].

Resource-based view of integration originated from the theory of the growth of the firm [13]. Barney [9] puts forward a more contemporary interpretation of RBV, emphasizing the importance of resources in guiding firm activity, transaction cost, and managing a firm's portfolio of capabilities as it is central to enhancing competitive advantage $[9,14]$. The definition of RBV theory describes the resources as either tangible or intangible and as both heterogeneous and imperfectly mobile among firms [10]. RBV theory has been studied extensively in business strategy in the past decade and has become a popular explanation of performance heterogeneity at the firm level $[15,16]$. According to RBV theory, firms seek complementary resource allocation to create synergies and acquire sustainable competitive advantages [17]. To respond quickly to a dynamic environment, firms should consider constructing and extending limited resources to develop a capability for sustainable competitive advantage [18].

The pharmaceutical industry utilizes project management aspects of scheduling arranged and resource allocation on $\mathrm{R} \& \mathrm{D}$ pipelines that is a practical approach to improving management performance [19]. Project planning and scheduling arranged has become an important management tool for today's complex investment environment [20, 21]. Project management can enhance resource allocation planning quality and help organizations upgrade their performance [22]. An efficient planning model that can aid firms in achieving optimal resource allocation and, consequently, the best resource allocation outcome is not only desirable but necessary for any organization. Through project management conduct an effectively integrating resource planning model for IC design service firm of IC semiconductor industry is expected.

\subsection{Through Alliance Planning Conduct Optimal Resource} Allocation Model. Integrating IC design service human resource into semiconductor industry has become an important issue in IC semiconductor industry. Moore and Benbasat [23] suggest developing an instrument to help firms enhance their adoption of information technology innovation. They regard firms as resource bundles for strategic alliance, capabilities, and competencies that provide a distinct source of competitive heterogeneity [24]. Faced with insufficient resources, firm should seek for more internal resources, and leverage external resources that support firm's research development and can reallocate resources according to needs and goals of organization. An efficient planning model would enhance the utilization rate of resources and improve R\&D performance. Through alliance planning integrate internal and external resources of IC semiconductor industry that can enhance business operation performance.

Competitive strategy is an important approach of management issue. Organizations considered competitive strategy very useful for resource planning and increasing efficiency across organizations management [25]. Both comparative advantages in resources allocation and resource deployment contribute to enhanced performance [26]. To achieve high performance of operational, the top managers should provide a conspicuous goal of strategic alliance direction [27]. Strategic alliance planning is an approach of management in defining a company's future progression direction and developing a plan for its development in the future [2831]. Integrating IC design human resources into IC design service through strategic alliances approach that can help firms improve business performance. The IC design service 
firm also can utilize strategy alliance planning to create much more added value on business operation.

\subsection{De Novo Programming Approach for Resource Allocation.} The classical De Novo programming method proposed by Zeleny $[5,32,33]$ is an effective approach in dealing with optimal design problems. Currently, system analysis and design have become important managerial and operational issues in many countries and regions of water resources [34]. The original idea of De Novo programming does not advocate production of individual or separate resources. Specially, the human resources are related and not independent of IC design firms. In the real world, it is virtually impossible to optimize all criteria when confronting a situation. The concept of trade-off then becomes useful when considering multiple criteria and when operating under limited resources. Zeleny [35] regards trade-offs as properties of an inadequately designed system and can thus be eliminated through designing a better, preferably optimal system. The De Novo programming approach can deal with an optimization problem solution with multiple criteria. Hence, this approach was adopted in this study to construct the integrating resources planning model that can be universally applied to the other case for different industries.

2.4. Open Innovation Theory. Open innovation has emerged as a new key theory in recent years. It is a novel model for organizing technological innovation in large $\mathrm{R} \& \mathrm{D}$ intensive firms [36]. According to open innovation model, firms can and should use both internal and external ideas and access the markets through both internal and external paths when they advance new technology [8]. Open innovation offers systematic incentives and explores a wide range of internal and external sources for innovative opportunities, consciously integrating such exploration with firm's capabilities and resources and broadly exploiting those opportunities through multiple channels [37]. Open innovation has become increasingly important for both practice and theory. Organizations need shorter innovation cycles time and lower R\&D costs.

The managerial challenges of open innovation involve utilizing external knowledge, then identifying useful external knowledge, and integrating that knowledge into firm. For example, new products have significant trade-offs between innovation speed, in new product development costs, and competitive advantage in relying on external knowledge rather than benefit in current internal knowledge [38]. The open innovation phenomenon is reinforced by increasing globalization of research, technologies and innovation, new information and communication technologies, and potentials of new organizational forms and business models [39].

Chesbrough et al. [36] show that the open innovation paradigm treats $\mathrm{R} \& \mathrm{D}$ as an open system, in which valuable ideas come from inside or outside of company and go to market from inside or spin-off from the firm (see Figure 1). This study combines the concepts of open innovation, strategic alliance, and De Novo programming approach that integrates IC design service firm's resource into IC semiconductors industry.

\section{Methodology}

As seen in the above discussion, integrated resources plays a central role in universal industry. Specially, in IC design service firm's allocates resource and promotes sustainability efforts. Next section explores the construction of an efficient planning model for strategy alliance alternative to integrating resources using De Novo programming.

3.1. Integrating Resource Allocation. The semiconductor industry face too many challenge including cost down, competitor treat, human resource constraint, and other resources limitation, which in turn affects IC design effectiveness and business operational performance. Optimal human resource allocation by mathematic programming thus becomes a key issue in IC design service firms. Mathematic programming distributes limited resources to competing activities to achieve optimal resource allocation. Linear programming is the most popular mathematic programming approach. Kantorovich and Koopmans [40] develop linear programming formula which can be described as follows

$$
\begin{array}{cc}
\operatorname{Max} \quad \mathbf{C x} \\
\text { s.t. } & \mathbf{A x} \leq \mathbf{b} \\
& \mathbf{x} \geq 0 .
\end{array}
$$

Here $\mathbf{C}=\mathbf{C}_{q \times n}$ and $\mathbf{A}=\mathbf{A}_{m \times n}$ are matrices, $\mathbf{b}=\left(b_{1}, \ldots\right.$, $\left.b_{m}\right)^{T} \in R^{m}$, and $\mathbf{x}=\left(x_{i}, \ldots, x_{j}, \ldots, x_{n}\right)^{T} \in R^{n}$. Let the $k$ th row of $C$ be denoted by $C^{k}=\left(c_{i}^{k}, \ldots, c_{j}^{k}, \ldots c_{n}^{k}\right) \in R^{n}$ and $C^{k} x$, $(k=1, \ldots, q)$ is the $k$ th evaluation criterion or alternative objective function. This linear programming problem can be solved in several ways, which include using the simplex method or the interior-point algorithm that allocates limited resource problems. Although mathematic programming offers a solution method to the resource allocation problems, it is unreasonable to assume additivity when extending this method to manage an alliance resource. This situation is base on additivity which presumes that all productive elements are independent and the total effects equal the summation of each individual effect. Such assumption does not fit firm's needs when the firm expects to create a synergies effect of business operations.

The concept of emerging mass customization has been proposed for solving the problem of element independence. Generally, a company can obtain profits in two ways. One is to increase revenue with higher unit price through customizing and the other is to reduce the cost of unit through max economic scale of production. With element independence, it is impossible to reduce cost of unit and increase revenue simultaneously. Utilizing the concept of mass customization can release limited element independence. This study assumes that there exists a market alliance between companies $A$ and $B$ with $\pi_{A}$ and $\pi_{B}$ denoting their respective profits. The goal of a company is to maximize profits, and the feasible solutions are within the space surrounded by dotted lines shown in Figure 2. Compromise solutions are typically the best decision in traditional mathematic programming and 


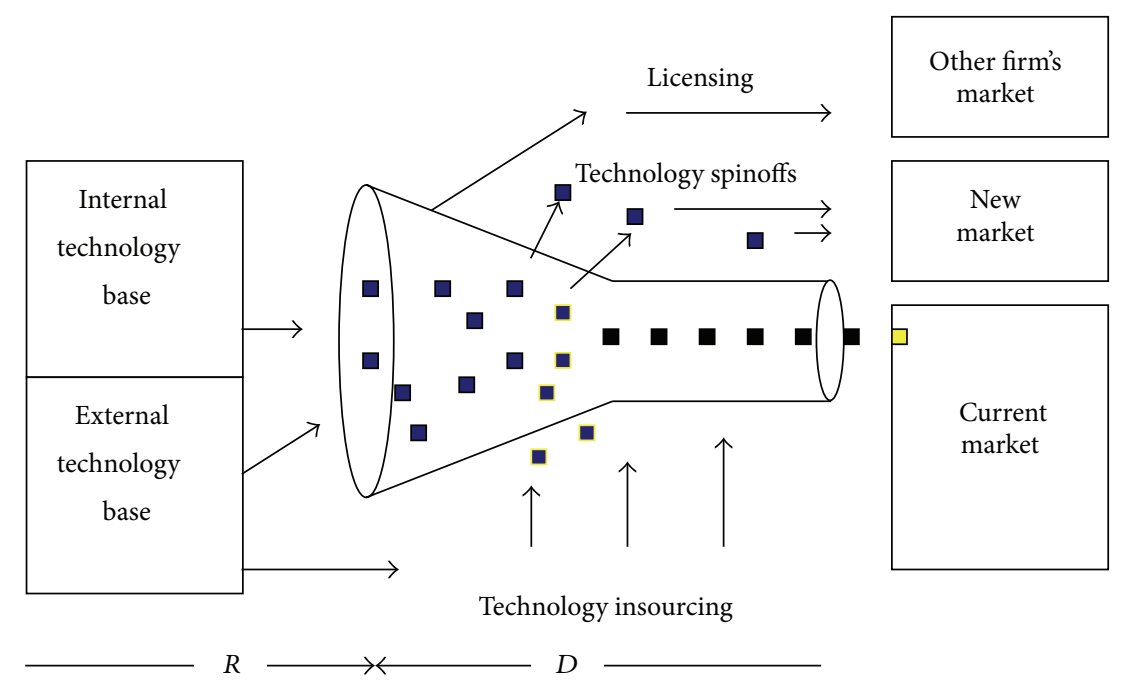

FIGURE 1: The open innovation paradigm (sources from [36]).

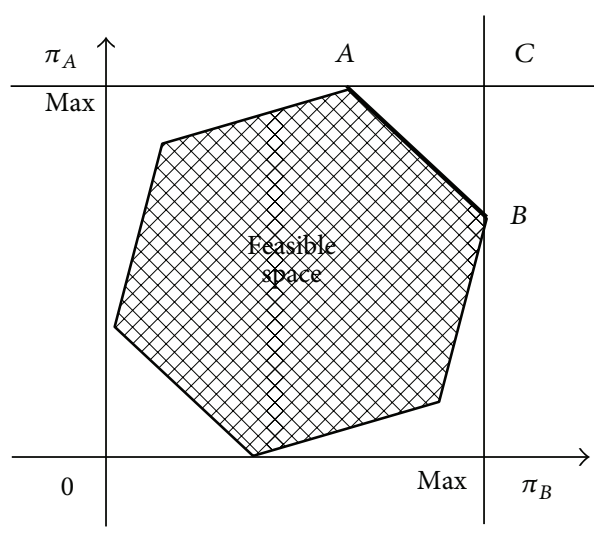

(a)

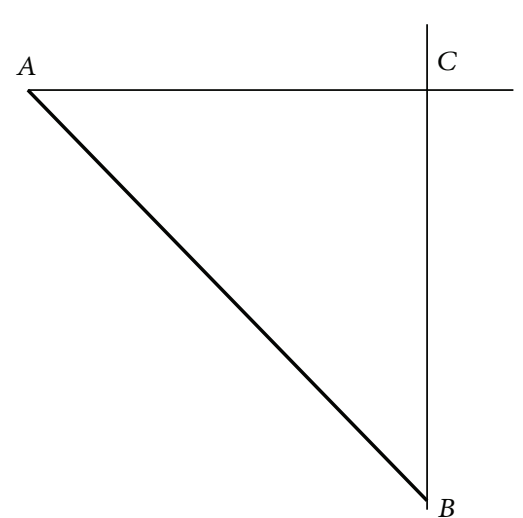

(b)

FIGURE 2: Feasible options obtained using linear programming.

they fall into $A \cap B$. Options space contained in points $A$, $B$, and $C$, that include the ideal point $C$, they are unavailable options space what caused with utilizing linear programming additivity.

According to the assumption of additivity, combining alliance resources allows not only $1+1=2$ but also can obtain $1+1>2$. Therefore, synergies concept are popular reasons for obtaining optima result through resource alliances [41]. In other words, traditional mathematic programming is rational and available when a firm has resource constraints that cannot change if it is produced individually [42]. However, the traditional method is no longer suitable when redesigning systems and the optimal solution was adopted through strategic alliances with difference firms.

This research uses De Novo programming to release limited element independence and to solve the problem of an optimal resource allocation portfolio through resource alliances to achieve the aspiration goal.
3.2. De Novo Programming for Alliances Approach. The De Novo programming is one of MCDM method that can remodify the systems to achieve an aspiration goal of firm's expectation. By releasing various constraints, the De Novo programming attempts to break limitations to achieve the optimal solution. Through formation strategic alliance and resource integration, the current work extends the De Novo programming to obtain an optimal solution [43-45]. The De Novo perspective combines transaction cost theory and resource-based view (RBV) to provide a holistic perspective for achieving an aspiration level [46]. In this research, firm seeks strategic alliance/resource integration according to firm's needs. If the minimum alliance cost lies between design cost and human resource cost, Semiconductor's firm should seek strategic alliance/resource integrated for IC design human resources sharing. The IC design service cost can be modified as if alliance/integration cost is less than individual firm's cost summary $\left(\leq \sum_{i=1}^{N}\right)$. 
The firm should seek alliance/integration with the other partner.

From the RBV view, firms seek resource alliances capabilities by allying with a partner to create synergies based on RBV theory. The rule of the RBV can also be modified as if alliance/integration benefit is larger than individual firm's profit summary $\left(\geq \sum_{i=1}^{N}\right)$. firms.

The firm should seek alliance/integration with the other

Now, we involve the cost and RBV theory into the De Novo programming, if the firm alternatives are based on two different resources $S$ and $T$, the rule of resource integrating can be expressed as follows:

$$
\text { if } E(S \cup T)-U\left(C_{S T}\right)>E(S)+E(T)-U\left(C_{S}\right)-U\left(C_{T}\right) \text {, }
$$

then the firm should seek resource integration with partner of industry cluster.

Also, it can express a general formula as follows

$$
\begin{aligned}
& \text { if } E\left(S_{1} \cup S_{2} \cdots \cup S_{N}\right)-U\left(C_{\text {alliance cost }}\right) \\
& \quad \geq \sum_{i=1}^{N}\left[E\left(S_{i}\right)-U\left(S_{i}\right)\right], \quad i=1,2, \ldots, N,
\end{aligned}
$$

where $E(\cdot)$ is the benefit function, $U(\cdot)$ is the cost function, $C_{S}$ and $C_{T}$ denote the total design cost in $S$ and $T$, respectively, and $C_{S T}$ denotes the alliance/integration cost between $S$ and $T$. The probability of $S$ and $T$ events seeking strategic alliance/resource integration can be demoted, respectively as

$$
\begin{aligned}
& p(s)= \begin{cases}1, & \lambda E(S \cup T)-\theta U\left(C_{S T}\right)>E(S)-U\left(C_{S}\right), \\
0, & \lambda E(S \cup T)-\theta U\left(C_{S T}\right)<E(S)-U\left(C_{S}\right),\end{cases} \\
& p(T)=\left\{\begin{array}{rr}
1, & (1-\lambda) E(S \cup T)-(1-\theta) U\left(C_{S T}\right) \\
0, & >E(T)-U\left(C_{T}\right), \\
& <E(T)-U\left(C_{T}\right),
\end{array}\right.
\end{aligned}
$$

where $\lambda$ denotes the percentage of increasing alliance benefit in $S$ and $\theta$ denotes the percentage of reducing alliance cost in $S$. Now, we can involve De Novo programming into the planning model of resource integrating that can be expressed as:

$$
\begin{array}{ll}
\max & E(S \cup T)-U\left(C_{S T}\right), \\
\text { s.t } & w x \leq B, x \geq 0,
\end{array}
$$

where $w=p A=\left(w_{1}, \ldots, w_{n}\right) \in R^{n}$ and $p=\left(p_{1}, \ldots, p_{m}\right) \in$ $R^{m}$ and $B \in R$ present the unit price of resources and the total available budget. Then, the knapsack solution is

$$
x^{*}=\left[0, \ldots, \frac{B}{C_{k}}, \ldots, 0\right]^{T},
$$

where

$$
\frac{c_{k}}{c_{k}^{*}}=\max _{j}\left(\frac{c_{j}}{c_{j}^{*}}\right),
$$

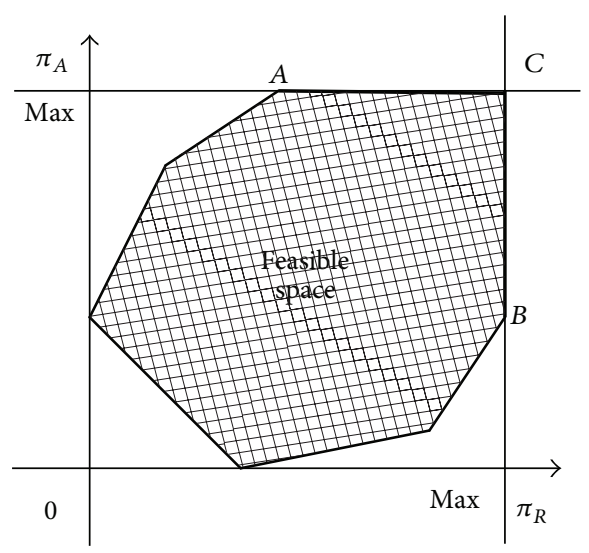

FIGURE 3: Feasible options obtained using De Novo programming.

The optimal solution to (5) is given by (6) and

$$
b^{*}=A x^{*},
$$

The final alliance/integration benefit $\left(\Psi\left(S^{*}\right)\right)$ in $S$ is

$$
\Psi\left(S^{*}\right)=i^{\prime} b^{*} U\left(-C_{S T}\right),
$$

where $i$ is the identity column vector. According to (9), we can judge whether or not the firm should seek strategic alliance/resource integration by (3), (4a), and (4b). Furthermore, using De Novo programming, we can easily achieve optimal resource allocation and create synergies between alliances. The difference between traditional mathematic programming and De Novo programming lies in the ability of the De Novo programming to redefine its boundaries through system redesign, reconfiguration, or reshaping [33]. Figure 3 shows the difference in feasible options space obtained through De Novo programming method.

The greatest difference between Figures 2 and 3 is that the unavailable solutions before were made available through De Novo programming now. In other words, the ideal point $C$ is the goal of optimal solution through strategic alliance/resource integrating approach.

\section{Empirical Study Practice}

It is commonly believed that integrating IC design human resources into IC semiconductor supply chain system can enhance operation performance, and such integration would require a complete planning model to ensure effectiveness. The proposed planning model is applied to IC design service firms in Taiwan as a empirical case study to examine the planning model feasibility.

4.1. The Case Study of Taiwan's IC Service Design Firm. Taiwan's semiconductors industry is a globalization business, specializing as the world's number one of DRAM IC foundry manufacturer. The IC semiconductors industry is a complete supply chain that includes IC design service, supplier, and customer. The IC supply chain system developed became firms cluster with difference supply chain speciality needs 


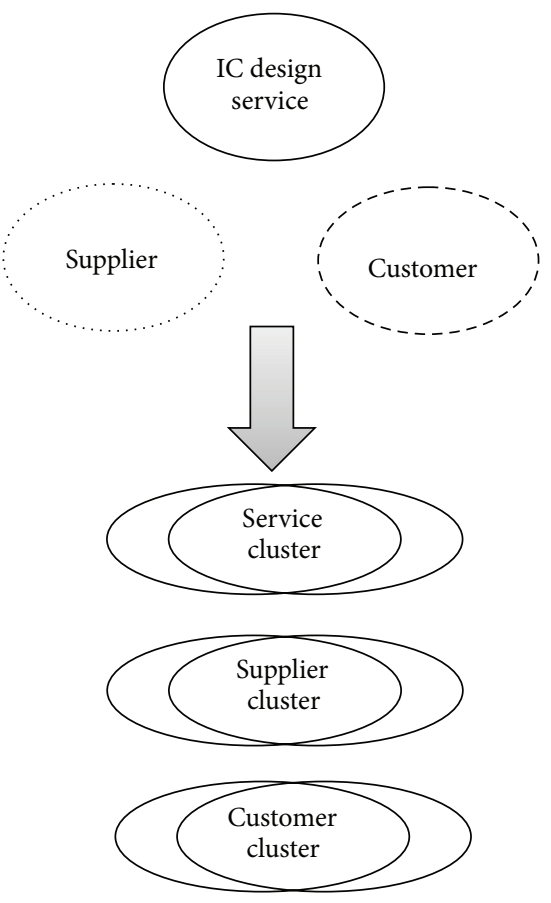

Figure 4: The supply chain of IC semiconductor industry.

(see Figure 4). The IC design service is one of semiconductor manufacturing processing before launching into IC foundry. The IC design service firms obtain the order from customer and through project management controls the design schedule for customer needs. More than 365 IC design service firms have been established around Hsinchu Science Park in Taiwan. This IC service design firm cluster situation is very special in the world. Consequently, studying Taiwan's IC design service firms is a very interesting empirical case.

4.2. The Problems of IC Semiconductor Industry. Currently, Taiwan's semiconductors face a very slow economics situation of business operation. Government release encourage policy try to save the semiconductor industry but these policies was fail. The economics of semiconductor continues going down of economic curve. The IC industry external environmental factors are multiples and dynamics, specializing on the IC design service sector. Also, the IC design service firm requires one high performance project management to help manage related task. Integrating internal human resource and leveraging external resource and adjusting business strategy for match customer needs of IC design market. As such, firms should offer just-in-time mechanism of services for products delivery and quick response system for customers. A little loss on service process could bring the result of lose customer. Therefore, IC design firm should determine to operate at lowest cost and high quality level for IC design service. High performance IC design service systems should be considered in the semiconductor supply chain system.

4.3. IC Design Service Firms. The IC design skill is one of key technical of IC semiconductor manufacturing system. It is a new business model emerging as a vertical disintegration product in the IC semiconductor industry. The IC semiconductor combines multiprocesses into one complete system, including IC design, and an IDM (integrated device manufacturer) fabrication assembly test in the 1970s. IC-designs and IDM were separated in the 1980s from one complete set system to develop two subsystems of IC design and IDM fabrication, and continues developing, including IC design and IDM fabrication and assembly. The IC semiconductor industry after the 1980s modified processing to include the system, IC design, IDM fabrication, IC foundry, IC assembly, and IC test on the subsystem. The IC design subsystem after 2001 extends from one to three parts, including SiP (system in package), design system, and IC design. The IC design service firm has become an important process of the IC semiconductors industry. Figure 5 shows IC design service development trajectory from 1960 to 2013.

The IC design service firm is a high technology knowledge industry. The IC design service firm requires professional human design who must have engineering background, specialized design technology knowledge, and also need high speed internet networks, a convenient communication digital platform, and a high operation performance. This study expects a building of an MCDM model with De Novo programming for integrating the resource of IC design service firms. The IC design service firm is multidimensional and highly competitive, focusing on special professional techniques, and quick response of design services. De Novo programming helps to plan service model for achieving aspiration levels of the IC design service firms.

4.4. The Relationship of IC Design Service, Supplier, and Customer. The IC semiconductors industry is a multiple production process that includes design, fabrication, foundry, testing, assembly, and delivery of products to customer. The IC design service is a substructure under the IC supplier, providing IC design service for supplier or customer. The IC design service firms offer system in package ( $\mathrm{SiP}$ ) design to direct customer or IC design and IC layout design for supplier (see Figure 6). The IC design service firms offers value added at each design service process, for example, highlighting performance, powerful function, low production cost, system on chip (SoC), and redownsizing IC design space. Figure 6 shows relationship between of IC design service, supplier, and customer.

The IC design service firms not only provides design service for IC semiconductors manufacturing systems but also offers new innovative ideas/function on IC chip for customer. The IC design service firms generally provides professional IC design knowledge and IC foundry techniques that can obtain greater economics efficiency of semiconductors production; the result should be increased IC design service business opportunity. Consequently, adopting innovative ideas becomes a very important task in IC design service processing.

4.5. Through De Novo Programming Achieving Aspiration Goal. This study expects through De Novo programming to 


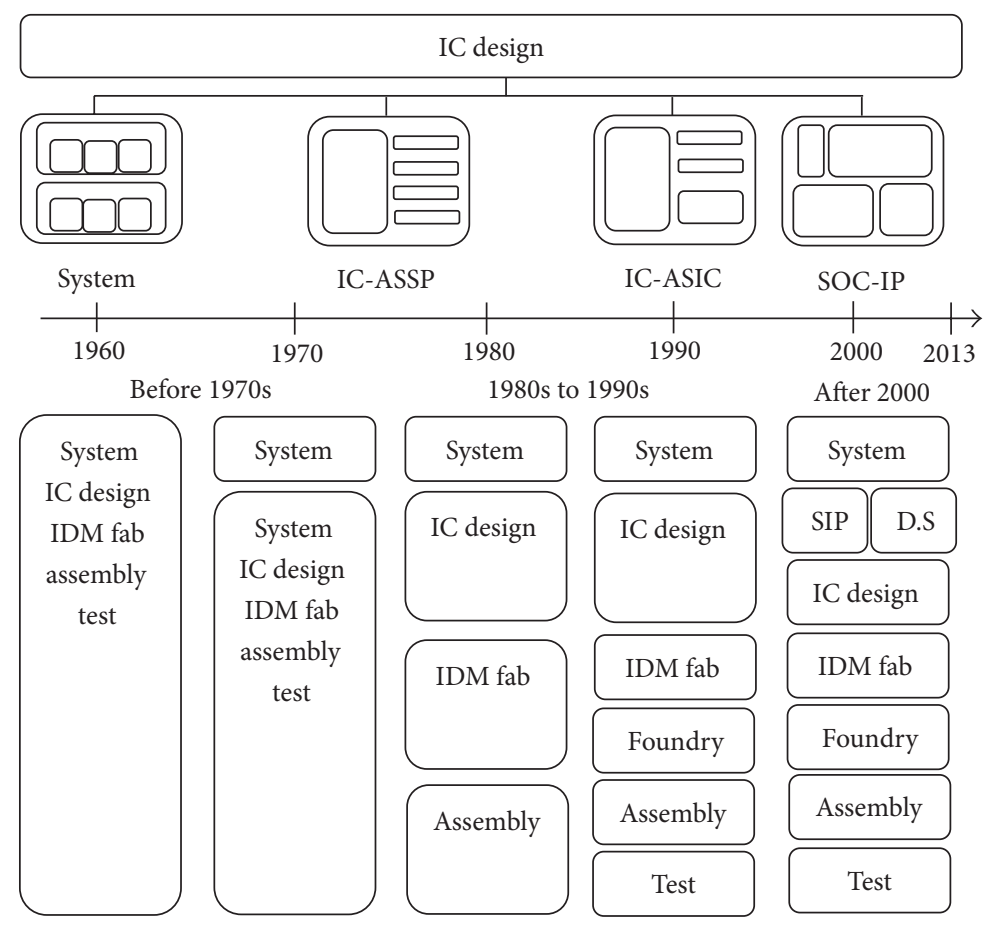

FIGURE 5: The IC design service development trajectory from 1960 to 2013 year.

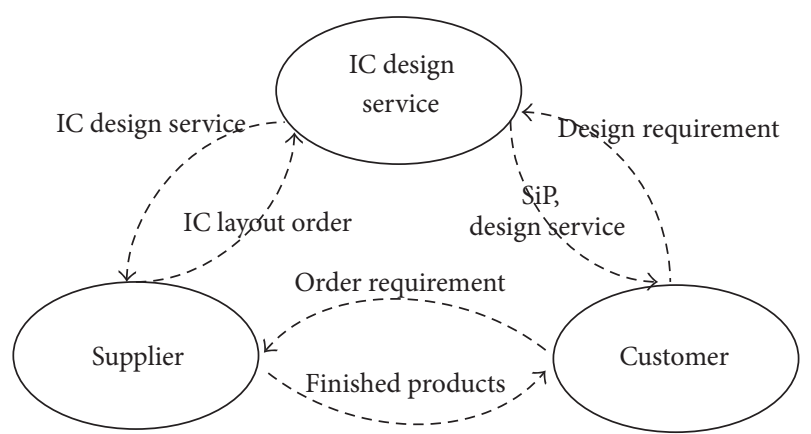

FIGURE 6: The relationship of IC design service, supplier, and customer.

achieve optimal resource integrating purpose. The IC design service firm must consider resource constrain under multiple objectives alternatives before making decisions. Firm face multiple objectives and evaluation criteria of problem, namely, dealing with resources integrating and adjusting business strategic to achieve the aspiration goal of business. In general, through trade-off skill it is almost impossible to obtain optimization of all criteria of a given system. Zeleny [32] states the new system can eliminate the resource constrain through redesign then preferably obtain optimization results what can improves the Trade-off problems. Zeleny [35] proposes the optimal portfolio resource allocation concept which designs a resource integrated system, that is, individual resource levels cannot determine separately, so new design systems do not have trade-offs to consider. Zeleny [33] develops a De Novo programming method for designing an

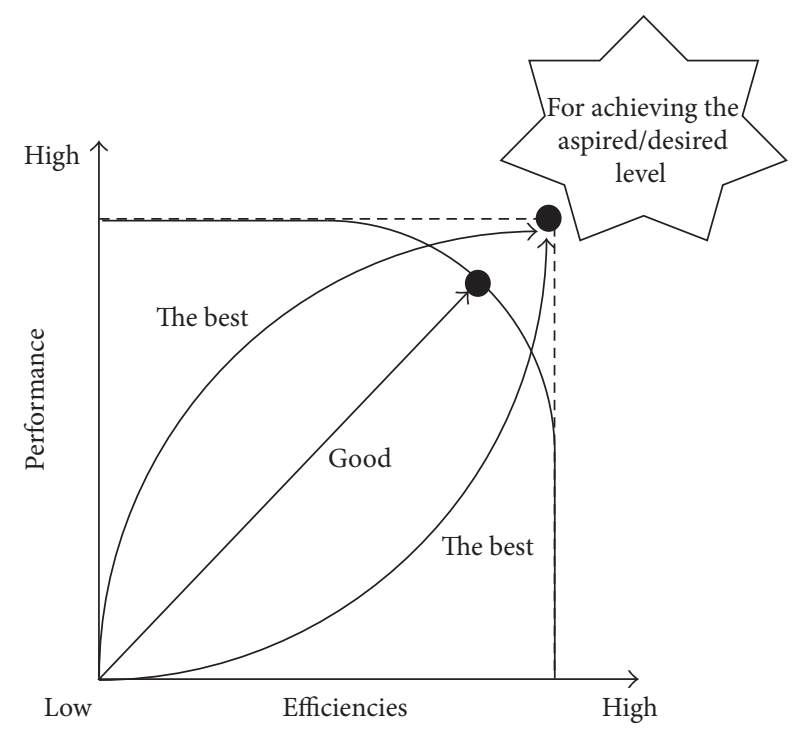

FIgURE 7: Through De Novo programming achieving the aspiration goal.

optimal system by reshaping the feasible set [33]. Firm can make strategy alliances with partner of supply chain system and achieves resource integration, adjusting the business goal, remodifying the business model, and justifying target customer services. This study expects through De Novo programming approach to compute the data of resource integrating and justify the resource allocation/objective alternative from a good level to best level, thus achieving aspiration goal (see Figure 7). 


\subsection{Empirical Case Study}

4.6.1. A Case Study of IC Production Firm. A general case of IC production problem involving two IC products: GPS and cell phone of IC, in quantities $x_{1}$ and $x_{2}$, each consuming five different resources (unit market prices of resources are given). The data is summarized as shown in Table 1.

The costs of the given resources portfolio

$$
\begin{aligned}
& (28 \times 32)+(35 \times 30)+(10 \times 55) \\
& \quad+(18 \times 10)+(10 \times 28)=\$ 2956 .
\end{aligned}
$$

Unit costs of producing one unit goods of the two products

$$
\begin{aligned}
x_{1}= & (28 * 6)+(35 * 3)+(10 * 14)+(18 * 2) \\
& +(10 * 6)=\$ 509, \\
x_{2}= & (28 * 2)+(35 * 5)+(10 * 6)+(18 * 5) \\
& +(10 * 8)=\$ 461 .
\end{aligned}
$$

Expected profit margins (price-cost) are

$$
\begin{aligned}
& \text { the profit of } x_{1} \text { product }=\$ 549-\$ 509=\$ 40 / \text { unit, } \\
& \text { the profit of } x_{2} \text { product }=\$ 491-\$ 461=\$ 30 / \text { unit. }
\end{aligned}
$$

Maximizing total value of function $f_{1}$

$$
f_{1}=40 x_{1}+30 x_{2} .
$$

Maximizing total quality index $f_{2}$

$$
f_{2}=8 x_{1}+10 x_{2} \text {. }
$$

Maximizing levels of two products calculated by De Novo programming

$$
\begin{array}{ll}
\max & f_{1}=40 x_{1}+30 x_{2}, \\
\max & f_{2}=8 x_{1}+10 x_{2}, \\
\text { s.t. } & 6 x_{1}+2 x_{2} \leq 32, \\
& 3 x_{1}+5 x_{2} \leq 30 \\
& 14 x_{1}+6 x_{2} \leq 55, \\
& 2 x_{1}+5 x_{2} \leq 10 \\
& 6 x_{1}+8 x_{2} \leq 28 \\
& x_{1}, x_{2} \geq 0 .
\end{array}
$$

Maximum $f_{1}$ in profit

$$
\begin{gathered}
\max f_{1} \longrightarrow x_{1}=3.71, \\
x_{2}=0.52, \\
f_{1}^{*}=40 \times 3.71+30 \times 0.52=\$ 164 .
\end{gathered}
$$

Maximum $f_{2}$ in total quality index

$$
\begin{gathered}
\max f_{2} \longrightarrow x_{1}=3.71, \\
x_{2}=0.52, \\
f_{2}^{*}=8 \times 3.71+10 \times 0.52=\$ 34.88 .
\end{gathered}
$$

Minimizing the total cost by considering the following constraints:

$$
\begin{array}{ll}
\min & 509 x_{1}+461 x_{2}, \\
\text { s.t. } & 40 x_{1}+30 x_{2} \leq 164, \\
& 8 x_{1}+10 x_{2} \leq 34.88 .
\end{array}
$$

Maximum $f_{1}$ in profit

$$
\begin{gathered}
\max f_{1} \longrightarrow x_{1}=3.71, \\
x_{2}=0.52, \\
f_{1}^{*}=40 \times 3.71+30 \times 0.52=\$ 164 .
\end{gathered}
$$

Maximum $f_{2}$ in total quality index

$$
\begin{gathered}
\max f_{2} \longrightarrow x_{1}=3.71, \\
x_{2}=0.52 ; \\
f_{2}^{*}=8 \times 3.71+10 \times 0.52=\$ 34.88 .
\end{gathered}
$$

Cost of the newly designed system

$$
\begin{aligned}
& (28 \times 23.28)+(35 \times 13.68)+(10 \times 55.06) \\
& \quad+(18 \times 10.02)+(10 \times 26.42)=\$ 2125.8 .
\end{aligned}
$$

The new portfolio of resources proposed by the consultant is shown in Table 2.

The result of data analysis shows that the new planning system cost is $\$ 2125.8$.

The given resource portfolio cost is $\$ 2956$. Comparison between original and new planning model, we found out that the new planning model can reduce cost to $\$ 830.5$ and that new resource planning model is one reliable model. Consequently, the IC design service firm can follow the new planning model of De novo programming to process resource integration.

4.6.2. The Case of IC Design Service Firm. The IC design service firm is a professional workshop that focuses on the IC design task dependent on what design they can provide service. The IC design service task is also a project-based planning under a large $R \& D$ project with business developing strategy. A project-based firm uses external delivery projects for business purposes $[47,48]$. This study utilizes a real case of IC design project management to practice on IC design service firm. Project planning may include many subprojects that depend on different cases of customer's demand. Central features of project management were identified according to individual project uniqueness, human resources of project and business network complexity, discontinuity of demand and relationships between other projects, and considerable financial commitment of the parties [49, 50]. Conducting aspiration project planning under resource constraint is a target issue for the IC design service firm. This real case includes five different resources which included human power resource, design equipments, design materials, special 
TABLE 1: The IC of GPS and cell phone production requiring material.

\begin{tabular}{lcccc}
\hline Unit price (\$) & Material of production process & \multicolumn{2}{c}{$\begin{array}{c}\text { Technological coefficients } \\
\text { (Resource requirement) }\end{array}$} & $\begin{array}{c}\text { Resource portfolio } \\
\text { (units) }\end{array}$ \\
\hline 28 & Silver wire & $x_{1}$ & 2 & 32 \\
35 & Golden wire & 6 & 5 & 30 \\
10 & Silicon Crystal & 3 & 6 & 55 \\
18 & Chemistry material & 14 & 5 & 10 \\
10 & Conductor material & 2 & 8 & 28 \\
\hline
\end{tabular}

TABLE 2: The new resource portfolio planning of IC of GPS and cell phone.

\begin{tabular}{lcccc}
\hline Unit price (\$) & Material of production process & \multicolumn{2}{c}{$\begin{array}{c}\text { Technological coefficients } \\
\text { (Resource requirement) }\end{array}$} & $\begin{array}{c}\text { Resource portfolio } \\
\text { (units) }\end{array}$ \\
\hline 28 & Silver wire & $x_{1}$ & 2 & 23.28 \\
35 & Golden wire & 6 & 5 & 13.68 \\
10 & Silicon Crystal & 3 & 6 & 55.06 \\
18 & Chemistry material & 14 & 5 & 10.02 \\
10 & Conductor material & 2 & 8 & 26.42 \\
\hline
\end{tabular}

technical human, and design outsourcing with two different project teams for the A company customer to perform the IC design task. The current study names the two projects as the $P_{1}$ and $P_{2}$ project team programs. This real planning program case utilizes the De Novo programming for adjustable resource allocation and seeks out minimum cost with maximum performance. This work transitions the five kinds of resources (design equipments, design human power, design material, special technical human, and designoutsourcing) in the case study to dollar amounts for easy cost calculation. Design equipments cost is $\$ 380$ per unit, design human power labor cost is $\$ 240$ per unit, design material resource cost is $\$ 200$, special technical human cost is $\$ 260$ per unit, and design outsourcing cost is $\$ 120$ per unit.

Costs of given resources portfolio

$$
\begin{aligned}
& (380 \times 26)+(240 \times 50)+(200 \times 30)+(120 \times 10) \\
& +(260 \times 16)=\$ 33240 .
\end{aligned}
$$

Unit costs for running each project of the two projects

$$
\begin{aligned}
P_{1}= & (380 * 8)+(240 * 10)+(200 * 4) \\
& +(260 * 6)=\$ 7800, \\
P_{2}= & (380 * 6)+(240 * 4)+(200 * 4) \\
& +(120 * 4)=\$ 4520 .
\end{aligned}
$$

Expected profit margins (price cost) are

$$
\begin{aligned}
& P_{1}=\$ 8200-\$ 7800=\$ 400 / \text { unit } \\
& P_{2}=\$ 4820-\$ 4520=\$ 300 / \text { unit. }
\end{aligned}
$$

Maximizing total value of function $f_{1}$

$$
f_{1}=400 p_{1}+300 p_{2}
$$

Maximizing total quality index $f_{2}$

$$
f_{2}=8 p_{1}+10 p_{2}
$$

Maximizing levels of the two projects calculated by De Novo programming

$$
\begin{array}{ll}
\max & f_{1}=400 p_{1}+300 p_{2} \\
\max & f_{2}=8 p_{1}+10 p_{2} \\
\text { s.t. } & 8 p_{1}+6 p_{2} \leq 26 \\
& 10 p_{1}+4 p_{2} \leq 50 \\
& 4 p_{1}+4 p_{2} \leq 30 \\
& 4 p_{2} \leq 10 \\
& 6 p_{1} \leq 16 \\
& p_{1}, p_{2} \geq 0
\end{array}
$$

Maximum $f_{1}$ in profit

$$
\begin{gathered}
\max f_{1} \longrightarrow p_{1}=2.67, \\
p_{2}=0.78 ; \\
f_{1}^{*}=400 \times 2.67+300 \times 0.78=\$ 1300 .
\end{gathered}
$$


TABLE 3: $P_{1}$ and $P_{2}$ project team program require resource of IC design service.

\begin{tabular}{lcccc}
\hline Unit price (\$) & Resources of IC design & \multicolumn{2}{c}{$\begin{array}{c}\text { Project coefficients } \\
\text { (Resource requirement) }\end{array}$} & $\begin{array}{c}\text { Resource portfolio } \\
\text { (units) }\end{array}$ \\
\hline 380 & $P_{1}$ & 6 & 26 \\
240 & Design equipments & 8 & 4 & 50 \\
200 & Human power resource & 10 & 4 & 30 \\
120 & Design material & 4 & 4 & 10 \\
260 & Design outsource & 0 & 0 & 16 \\
\hline
\end{tabular}

TABLE 4: The new resource portfolio planning model of $P_{1}$ and $P_{2}$ project team program.

\begin{tabular}{lcccc}
\hline Unit price (\$) & Resources of IC design & \multicolumn{2}{c}{$\begin{array}{c}\text { Project coefficients } \\
\text { (Resource requirement) }\end{array}$} & $\begin{array}{c}\text { Resource portfolio } \\
\text { (units) }\end{array}$ \\
\hline 380 & Design equipments & $P_{1}$ & 6 & 26 \\
240 & Human power resource & 8 & 4 & 32.5 \\
200 & Design material & 10 & 4 & 13 \\
120 & Design outsource & 4 & 4 & 0 \\
260 & Special technical human & 0 & 0 & 19.5 \\
\hline
\end{tabular}

Maximum $f_{2}$ in total quality index

$$
\begin{gathered}
\max f_{2} \longrightarrow p_{1}=2.67, \\
p_{2}=0.78, \\
f_{2}^{*}=8 \times 2.67+10 \times 0.78=\$ 29.16 .
\end{gathered}
$$

Minimizing the total cost by considering the following constraints:

$$
\begin{aligned}
& \min \quad 7800 p_{1}+4520 p_{2}, \\
& \text { s.t. } \quad f_{1}=400 p_{1}+300 p_{2} \leq 1300, \\
& f_{2}=8 p_{1}+10 p_{2} \leq 29.16 .
\end{aligned}
$$

Maximum $f_{1}$ in profit

$$
\begin{aligned}
\max f_{1} \longrightarrow p_{1}=3.25 \\
p_{2}=0 \\
f_{1}^{*}=400 \times 3.25=\$ 1300 .
\end{aligned}
$$

Maximum $f_{2}$ in total quality index

$$
\begin{gathered}
\max f_{2} \longrightarrow p_{1}=3.25 \\
p_{2}=0 \\
f_{2}^{*}=8 \times 3.25=\$ 26 .
\end{gathered}
$$

Cost of new design planning

$$
\begin{aligned}
(380 & \times 26)+(240 \times 32.5)+(200 \times 13)+(260 \times 19.5) \\
& =\$ 25350 .
\end{aligned}
$$

New portfolio of resources proposed by the consultant is shown in Table 4.

\subsection{Discussions}

4.7.1. The General Case of IC Production Firm. The data show the empirical case study using the De Novo programming which remodifies the planning model and adjusts the resources allocation portfolio. The new plan model offers the best optimized resource integration and reduces losing and enhances firm's competitiveness. Technical problems programming are discussed as follows.

(i) The original plan needs a total cost of $\$ 2956$ with given resources portfolios.

$$
\begin{aligned}
& {[(28 \times 32)+(35 \times 30)+(10 \times 55)+(18 \times 10)} \\
& +(10 \times 28)=\$ 2956] .
\end{aligned}
$$

(ii) The new planning model of resource allocation only requires cost of $\$ 2125.8$.

$$
\begin{aligned}
& {[(28 \times 23.28)+(35 \times 13.68)+(10 \times 55.06)} \\
& +(18 \times 10.02)+(10 \times 26.42)=\$ 2125.8] .
\end{aligned}
$$

(iii) The newly planning model can save $\$ 830.2$ cost. Consequently, firm seeks new planning model to integrate resource:

$$
\$ 2956-\$ 2125.8=\$ 830.2 \text {. }
$$

(iv) The newly planning model use the De Novo programming to reduce resource loss and get better performance than the original planning model. This paper also utilizes the empirical case examination of De Novo programming for IC design service firm performance. The new planning model obtains much better resource integration. 
4.7.2. The Case of IC Design Service Firm. Firms have mass production capacity limitation per one time period due to limited resources, especially for the preceding competitive facility location problem on the decentralized supply chain [51]. The IC design service firm is a standard project-based program model. Many project teams program through cooperation under a large design program for different customer are needed. This study utilizes a case study of IC design firm for planning an IC design to customer service. This case study includes two project teams. The $P_{1}$ and $P_{2}$ project with two different plan programming on IC design see (Table 3 ). One project team leader prefers hiring a special technical engineer for the IC design task that can maintain the IC design key technician and train other staff. The other project team leader prefers outsourcing design that reduces cost. The IC design service firm chooses the alternative optimal project team based on the result of De Novo programming.

The resource portfolio of firm's original cost is as follows:

$$
\begin{aligned}
& (380 \times 26)+(240 \times 50)+(200 \times 30)+(120 \times 10) \\
& +(260 \times 16)=\$ 33240 .
\end{aligned}
$$

The cost of newly planning model through the De Novo programming is as follows:

$$
\begin{aligned}
(380 & \times 26)+(240 \times 32.5)+(200 \times 13)+(260 \times 19.5) \\
& =\$ 25350 .
\end{aligned}
$$

The new planning model saves cost as follows:

$$
\$ 33240-\$ 25350=\$ 7890 \text {. }
$$

The IC design firm adopting $P_{1}$ project team cost is as follows:

$$
p_{1}(8 \times 26)+(10 \times 32.5)+(4 \times 13)+(6 \times 19.5)=\$ 702 \text {. }
$$

The IC design firm adopting $P_{2}$ project team cost is as follows:

$$
p_{2}(6 \times 26)+(4 \times 32.5)+(4 \times 13)=\$ 338 \text {. }
$$

The result of data analysis shows through the De Novo programming method the IC design service firm that can find out which project team is the optimal solution. In this empirical case adopting $P_{2}$ project team can save design cost much more than $P_{1}$ project. The new planning model reduces $\$ 7890$ in cost compared with the original planning model. So, the newly planning model is the best choice for achieving aspiration goal.

\section{Conclusion}

The IC semiconductor industry faces uncertainty and dynamic external environment especially at IC design service firm that needs one resource integrating programming model for new product development [52]. Adopting an efficient strategic alliances/resource integrating planning model is a key issue for achieving firm's business goals, especially as their resource was constrained. The present study considers a planning model based on resource constraints. This study utilizes the De Novo programming for achieving firm's strategic goal. The De Novo programming can help firms find out an optimal resource integration base on firm financial consider. This planning model provided reliable systematize approach that combines alliances from external resources and change them to internal resources application. The project team $P_{2}$ adopting open innovation concept through outsourcing reduces design cost and enhances design performance. De Novo programming not only obtains optimal resource integration but also promotes the conceptual of strategic alliances for firm's cooperation between each other.

5.1. Management Implication. This research aims to create a resource integrating plan model through IC design service firm as an empirical case for examining the result of the planning model. The planning model is based on open innovation theory exploring the IC design service firm which integrates IC design resources and makes optimal resources integrate in IC design service firm. The planning model of De Novo programming is not only for IC design service firm but also can apply to the other industrial implementation strategic alliance/resource integration. This planning model is a universal model for the other industry fields.

5.2. Suggestion. The IC design service industry is a very special industry. We suggest the extend to the other industry that can find out different results. Suggestion utilizes the other approach of MCDM method exploring different case studies of industry.

\section{Conflict of Interests}

The authors declare that there is no conflict of interests regarding the publication of this paper.

\section{Acknowledgments}

The authors appreciate two blind reviewers who have provided very excellent comments. These comments are very good for the authors to improve the quality of the paper. Also, thanks to the editor Professor Chang for offering lots of excellent suggestions that helped enhance this paper's quality.

\section{References}

[1] R. Varadarajan, "Outsourcing: think more expansively," Journal of Business Research, vol. 62, no. 11, pp. 1165-1172, 2009.

[2] G. Forgionne and Z. Guo, "Internal supply chain coordination in the electric utility industry," European Journal of Operational Research, vol. 196, no. 2, pp. 619-627, 2009.

[3] R. George and R. Kabir, "Business groups and profit redistribution: a boon or bane for firms?" Journal of Business Research, vol. 61, no. 9, pp. 1004-1014, 2008.

[4] L. Duckstein and S. Opricovic, "Multiobjective optimization in river basin development," Water Resources Research, vol. 16, no. 1, pp. 14-20, 1980. 
[5] M. Zeleny, "A case study in multiple objective design: De Novo programming," in Multiple Criteria Analysis, Operational Methods, vol. 1, pp. 37-52, 1981.

[6] M. Zeleny, "Optimal system design with multiple criteria: De Novo programming approach," Engineering Costs and Production Economics, vol. 10, no. 1, pp. 89-94, 1986.

[7] S. Christophersona, M. Kitsonb, and J. Michiec, "Innovation, networks and knowledge exchange," Cambridge Journal of Regions, Economy and Society, vol. 1, no. 2, pp. 165-173, 2008.

[8] H. W. Chesbrough, Open Innovation: The New Imperative for Creating and Profiting from Technology, Harvard Business School Press, Boston, Mass, USA, 2003.

[9] J. B. Barney, "Firm resources and sustained competitive advantage," Advances in Strategic Management, vol. 17, pp. 203-227, 2000.

[10] B. Wernerfelt, "A resource-based view of the firm," Strategic Management Journal, vol. 5, no. 2, pp. 171-180, 1984.

[11] T. R. Holcomb and M. A. Hitt, "Toward a model of strategic outsourcing," Journal of Operations Management, vol. 25, no. 2, pp. 464-481, 2007.

[12] D. J. Collis, "A resource-based analysis of global competition: the case of the bearings industry," Strategic Management Journal, vol. 12, no. 1, pp. 49-68, 1991.

[13] E. Penrose, The Theory of the Growth of the Firm, John Wiley and Sons, New York, NY, USA, 1959.

[14] E. Anderson and H. Gatignon, "Modes of foreign entry: a transaction cost analysis and propositions," Journal of International Business Studies, vol. 17, no. 3, pp. 1-26, 1986.

[15] J. Chimhanzi and R. E. Morgan, "Explanations from the marketing/human resources dyad for marketing strategy implementation effectiveness in service firms," Journal of Business Research, vol. 58, no. 6, pp. 787-796, 2005.

[16] J. Fahy, "A resource-based analysis of sustainable competitive advantage in a global environment," International Business Review, vol. 11, no. 1, pp. 57-78, 2002.

[17] M. A. Harrison, R. E. Hoskisson, and D. Ireland, "Synergies and post acquisition performance: differences versus similarities in resource allocations," Journal of Management, vol. 17, no. 1, pp. 173-190, 1991.

[18] D. J. Teece, G. Pisano, and A. Shuen, "Dynamic capabilities and strategic management," Strategic Management Journal, vol. 18, no. 7, pp. 509-533, 1997.

[19] V. A. Varma, J. F. Pekny, G. E. Blau, and G. V. Reklaitis, "A framework for addressing stochastic and combinatorial aspects of scheduling and resource allocation in pharmaceutical R\&D pipelines," Computers and Chemical Engineering, vol. 32, no. 4-5, pp. 1000-1015, 2008.

[20] R. Kolisch, "Efficient priority rules for the resource-constrained project scheduling problem," Journal of Operations Management, vol. 14, no. 3, pp. 179-192, 1996.

[21] R. Kolisch and S. Hartmann, "Experimental investigation of heuristics for resource-constrained project scheduling: an update," European Journal of Operational Research, vol. 174, no. 1, pp. 23-37, 2006.

[22] M. J. Leiblein, “The choice of organizational governance form and performance: predictions from transaction cost, resourcebased, and real options theories," Journal of Management, vol. 29, no. 6, pp. 937-961, 2003.

[23] G. C. Moore and I. Benbasat, "Development of an instrument to measure the perceptions of adopting an information technology innovation," Information Systems Research, vol. 2, no. 3, pp. 192222, 1991.
[24] R. E. Hoskisson, M. A. Hitt, W. P. Wan, and D. Yiu, "Theory and research in strategic management: swings of a pendulum," Journal of Management, vol. 25, no. 3, pp. 417-456, 1999.

[25] C. C. Miller and L. B. Cardinal, "Strategic planning and firm performance: a synthesis of more than two decades of research," Academy of Management Journal, vol. 37, no. 6, pp. 1649-1665, 1994.

[26] S. D. Hunt, A General Theory of Competition, Sage, Thousand Oaks, Calif, USA, 2000.

[27] S. Hart and C. Banbury, "How strategy-making processes can make a difference," Strategic Management Journal, vol. 15, no. 4, pp. 251-269, 1994.

[28] E. Drakopoulos, "Enterprise network planning and design: methodology and application," Computer Communications, vol. 22, no. 4, pp. 340-352, 1999.

[29] V. Kumar, B. Maheshwari, and U. Kumar, "ERP systems implementation: best practices in Canadian government organizations," Government Information Quarterly, vol. 19, no. 2, pp. 147$172,2002$.

[30] W. R. Lewis, “Strategic planning," Hospital Materiel Management Quarterly, vol. 10, no. 4, pp. 57-63, 1989.

[31] D. Wainwright and T. Waring, "Three domains for implementing integrated information systems: redressing the balance between technology, strategic and organisational analysis," International Journal of Information Management, vol. 24, no. 4, pp. 329-346, 2004.

[32] M. Zeleny, "Optimal system design with multiple criteria: De Novo programming approach," Engineering Costs and Production Economics, vol. 10, no. 1, pp. 89-95, 1986.

[33] M. Zeleny, "Optimal given system versus designing optimal system: the De Novo programming approach," International Journal of General System, vol. 17, no. 3, pp. 295-307, 1990.

[34] Y. M. Zhang, G. H. Huang, and X. D. Zhang, "Inexact de Novo programming for water resources systems planning," European Journal of Operational Research, vol. 199, no. 2, pp. 531-541, 2009.

[35] M. Zeleny, "Trade-offs free management via De Novo programming," International Journal Operations and Quantitative Management, vol. 1, no. 1, pp. 3-13, 1995.

[36] H. Chesbrough, W. Anhaverbeke, and J. West, Eds., Open innovation: Researching a New Paradigm, Oxford University Press, 2006.

[37] J. West and S. Gallagher, "Challenges of open innovation: the paradox of firm investment in open-source software," $R$ \& $D$ Management, vol. 36, no. 3, pp. 319-331, 2006.

[38] E. H. Kessler, P. E. Bierly, and S. Gopalakrishnan, "Internal versus external learning in new product development: effects on speed, costs and competitive advantage," $R$ \& D Management, vol. 30, no. 3, pp. 213-223, 2000.

[39] O. Gassmann and E. Enkel, "Towards a theory of open innovation: three core process archetypes," in Proceedings of the R\&D Management Conference (RADMA '04), Lisbon, Portugal, 2004.

[40] L. V. Kantorovich and T. C. Koopmans, Problems of Application of Optimization Methods in Industry, Federation of Swedish Industry, 1976.

[41] T. K. Das and B.-S. Teng, "A resource-based theory of strategic alliances," Journal of Management, vol. 26, no. 1, pp. 31-61, 2000.

[42] Z. Babic and I. Pavic, "Multicriterial production planning by De Novo programming approach," International Journal of Production Economics, vol. 43, no. 1, pp. 59-66, 1996.

[43] J. K. C. Chen and G. H. Tzeng, "Perspective strategic alliance and resource allocation in supply chain systems through the De 
Novo programming approach," International Journal Sustainable Strategic Management, vol. 1, no. 3, pp. 320-339, 2009.

[44] J.-J. Huang, G.-H. Tzeng, and C.-S. Ong, "Motivation and resource-allocation for strategic alliances through the De Novo perspective," Mathematical and Computer Modelling, vol. 41, no. 6-7, pp. 711-721, 2005.

[45] J.-J. Huang, G.-H. Tzeng, and C.-S. Ong, "Choosing best alliance partners and allocating optimal alliance resources using the fuzzy multi-objective dummy programming model," Journal of the Operational Research Society, vol. 57, no. 10, pp. 1216-1223, 2006.

[46] R. M. Grant, "The resource-based theory competitive advantage: implications for strategy formulation," California Management Review, vol. 33, no. 3, pp. 114-135, 1991.

[47] K. A. Artto and K. Wikström, "What is project business?" International Journal of Project Management, vol. 23, no. 5, pp. 343-353, 2005.

[48] J. Söderlund, "On the broadening scope of the research on projects: a review and a model for analysis," International Journal of Project Management, vol. 22, no. 8, pp. 655-667, 2004.

[49] B. Cova, P. Ghauri, and R. Salle, Project Marketing, Beyond Competitive Bidding, John Wiley \& Sons, Chichester, UK, 2002.

[50] T. Mandjàk and Z. Veres, "The D-U-C model and the stages of the project marketing process," in Proceedings of the 14th IMP Annual Conference Proceedings, H. K. Nummela, Ed., pp. 471490, 1998.

[51] Q. Meng, Y. Huang, and R. L. Cheu, "Competitive facility location on decentralized supply chains," European Journal of Operational Research, vol. 196, no. 2, pp. 487-499, 2009.

[52] H.-M. Hsu and W.-P. Wang, "Dynamic programming for delayed product differentiation," European Journal of Operational Research, vol. 156, no. 1, pp. 183-193, 2004. 


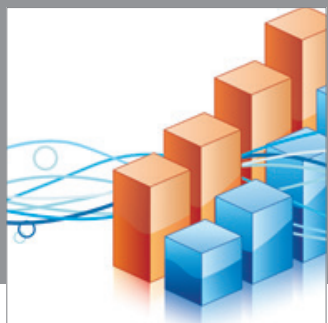

Advances in

Operations Research

mansans

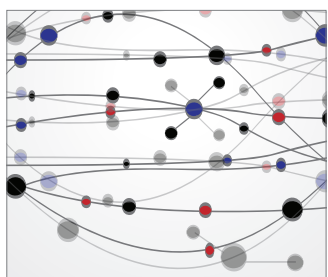

The Scientific World Journal
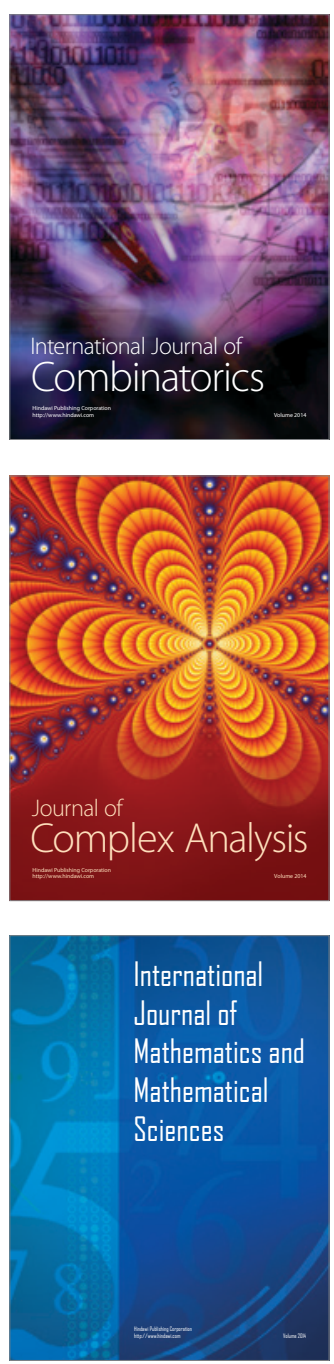
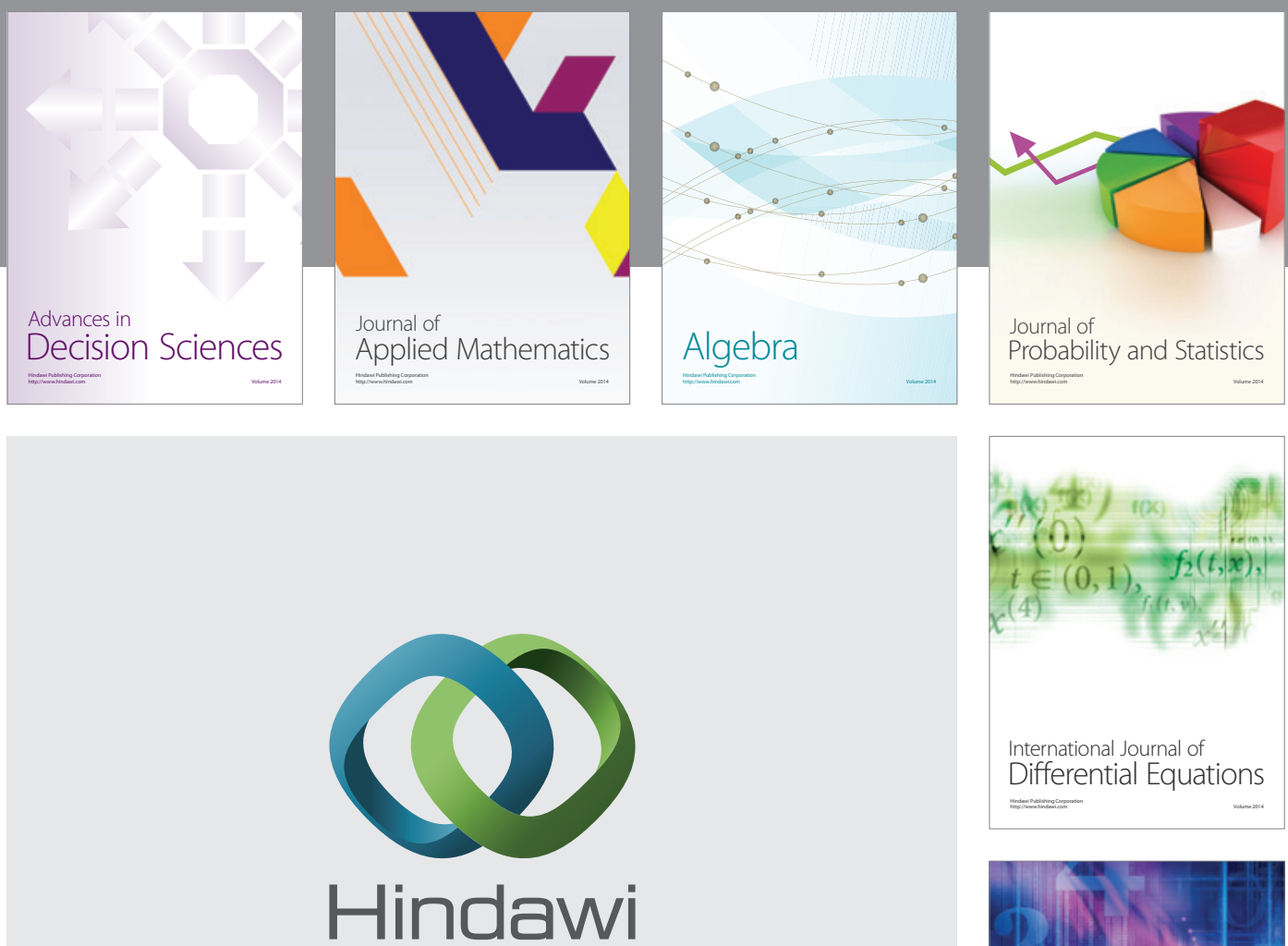

Submit your manuscripts at http://www.hindawi.com
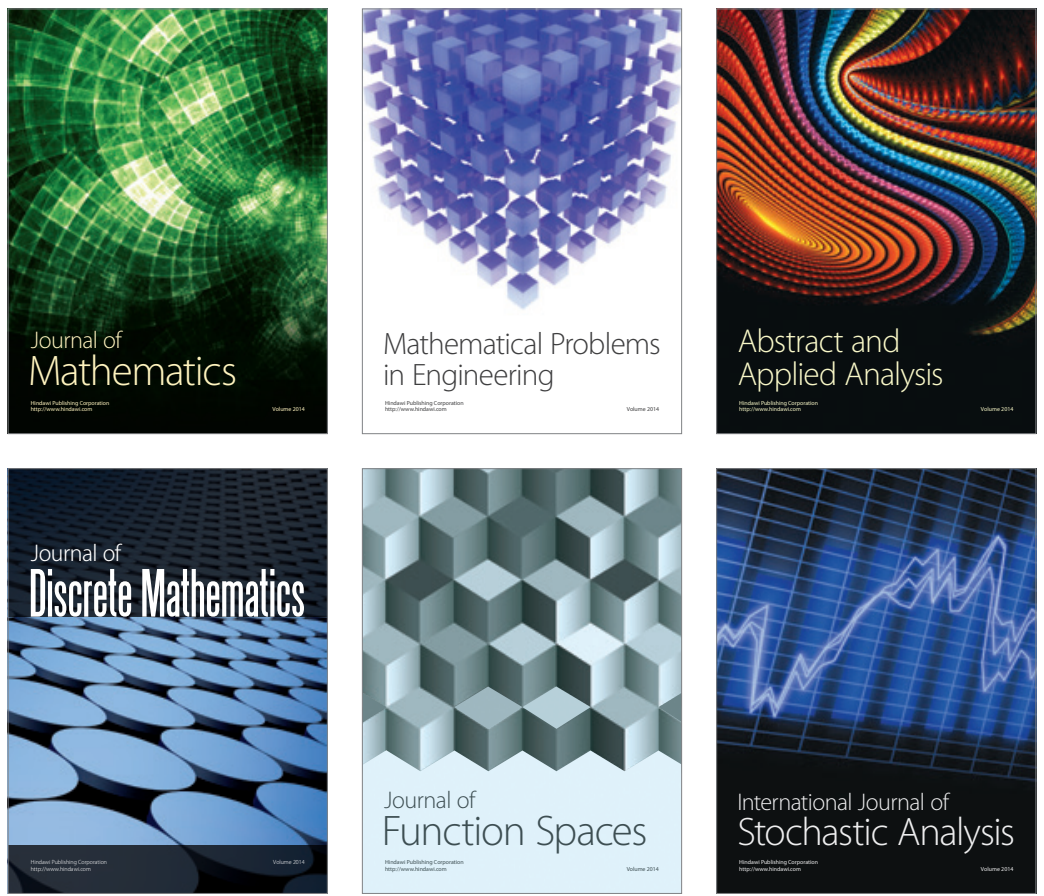

Journal of

Function Spaces

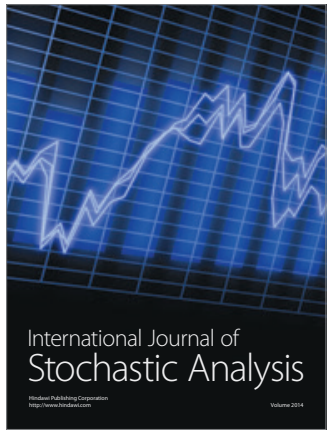

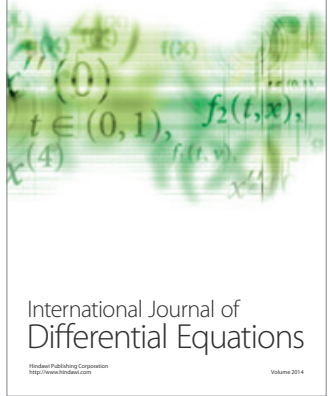
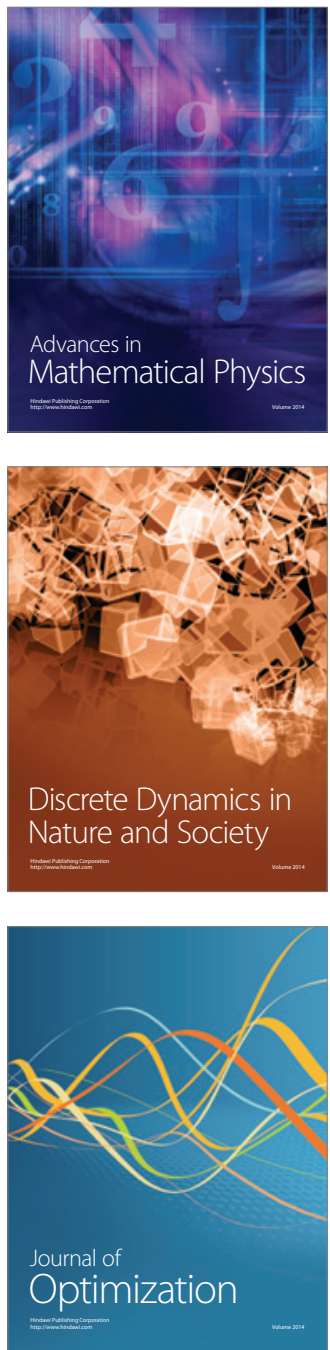